\title{
Respons Morfologi dan Anatomi Kecambah Kacang Kedelai (Glycine max (L.) Merill) terhadap Intensitas Cahaya yang Berbeda (Morphological and Anatomical Responses of The Soybean (Glycine max (L.) Merill) Sprouts to The Different Light Intensity)
}

\author{
Lisa Indried Pantilu ${ }^{1)^{*}}$, Feky $R$ Mantiri'), Nio Song $A{ }^{2)}{ }^{2)}$, Dingse Pandiangan ${ }^{2)}$ \\ ${ }^{1)}$ Alumni Jurusan Biologi Fakultas MIPA Universitas Sam Ratulangi Manado \\ 2) Jurusan Biologi Fakultas MIPA Universitas Sam Ratulangi Manado \\ ${ }^{*}$ E-mail korespondensi: dolpin_leezh@yahoo.com
}

Diterima 10 Mei 2012, diterima untuk dipublikasikan 28 Juli 2012

\begin{abstract}
Abstrak
Pengembangan tanaman kedelai sebagai tanaman sela di bawah tegakan karet, hutan tanaman industri (HTI), atau tumpangsari dengan tanaman pangan semusim lain merupakan alternatif andalan untuk meningkatkan produksi kedelai. Penelitian ini bertujuan untuk mengamati respons morfologi dan anatomi kecambah kacang kedelai pada stadium vegetatif 3 terhadap perbedaan intensitas cahaya. Penelitian ini dilakukan dengan menggunakan Rancangan Acak Lengkap (RAL) dengan satu faktor tunggal yaitu intensitas cahaya, dengan tiga taraf perlakuan yaitu P0 (tanpa naungan), $P 1$ (naungan paranet 1 lapis untuk naungan $\pm 50 \%$ ) dan $P 2$ (naungan paranet 2 lapis untuk naungan $\pm 90 \%$ ) dalam tiga kali ulangan. Penelitian ini menggunakan satu varietas kacang kedelai. Morfologi tanaman kedelai pada stadium vegetatif 3 dipengaruhi oleh intensitas cahaya. Hasil uji ANOVA yang dilanjutkan dengan BNT (5\%) menunjukkan tinggi tanaman pada $P 2$ dua kali lebih besar dibandingkan dengan tinggi tanaman pada P0; jumlah daun tidak berbeda antara perlakuan $P O$ dengan $P 1$ dan antara $P 1$ dan P2, tetapi jumlah daun pada P2 lebih banyak dibandingkan dengan jumlah daun pada $P O$ dan luas daun pada $P O$ lebih besar dibandingkan dengan luas daun P1 dan P2. Anatomi tanaman kedelai (jumlah, panjang, dan diameter stomata) pada stadium vegetatif 3 tidak dipengaruhi oleh intensitas cahaya.

Kata kunci: anatomi, cahaya, kedelai, morfologi, naungan
\end{abstract}

\begin{abstract}
Development of soybean plants as a plant stand waiting at the bottom of the rubber, plantation forests (HTI), or intercropped with other annual scropsis an alternative pledge to increase soybean production. This study aimed to observe the morphological and anatomical responses of soybean sprouts at the vegetative stage 3 of the difference in light intensity. The research was conducted using Completely Randomized Design(CRD) with one single factor is the influence of light, with a three-stage treatment of PO(without shade), P1(1 layer paranet shade to shade $\pm 50 \%$ ) and P2(2 layers for shading paranet auspices of $\pm 90 \%$ ) in three replications. This study uses one variety of soybeans. Morphology of soybean plants at the vegetative stage 3 is influenced by light intensity. ANOVA test followed by $L S D(5 \%)$ plant height at $P 2$ showed two times greater than the height of plants at $P 0$; number of leaves did not differ between treatments $P 0$ with $P 1$ and between $P 1$ and $P 2$, but the number of leaves on $P 2$ more than with the number of leaves on leaf area at $P O$ and $P O$ is greater leaf area compared with P1 and P2. Anatomy of soybean plants (number, length and diameter of the stomata) in the vegetative stage 3 is not affected by light intensity.

Keywords: anatomy, light, morphology, shade, soybean
\end{abstract}




\section{PENDAHULUAN}

Cahaya merupakan faktor esensial untuk pertumbuhan dan perkembangan tanaman. Cahaya berperan penting dalam proses fisiologi tanaman, terutama fotosintesis, respirasi, dan transpirasi. Unsur radiasi matahari yang penting bagi tanaman ialah intensitas cahaya, kualitas cahaya, dan lamanya penyinaran. Bila intensitas cahaya yang diterima rendah, maka jumlah cahaya yang diterima oleh satuan luas permukaan daun dalam jangka waktu tertentu rendah (Gardner et al. 1991).

Pada kebanyakan tanaman, kemampuan tanaman dalam mengatasi cekaman intensitas cahaya rendah tergantung kepada kemampuannya melanjutkan fotosintesis dalam kondisi kekurangan cahaya, seperti yang dilaporkan oleh beberapa peneliti sebelumnya. Hale dan Orcutt (1987) menjelaskan bahwa adaptasi tanaman terhadap intensitas cahaya rendah melalui dua cara, yaitu peningkatan luas daun untuk mengurangi penggunaan metabolit dan mengurangi jumlah cahaya yang ditransmisikan dan yang direfleksikan.

Levitt (1980) menggolongkan adaptasi tanaman terhadap naungan melalui dua mekanisme yaitu mekanisme penghindaran (avoidance) dan mekanisme toleransi (tolerance). Mekanisme penghindaran berkaitan dengan perubahan anatomi dan morfologi daun untuk memaksimalkan penangkapan cahaya dan fotosintesis yang efisien, seperti peningkatan luas daun dan kandungan klorofil b, serta penurunan tebal daun, rasio klorofil a/b, jumlah kutikula, lilin, bulu daun, dan pigmen antosianin. Mekanisme toleransi (tolerance) berkaitan dengan penurunan titik kompensasi cahaya serta respirasi yang efisien. Tanaman naungan ditandai dengan rendahnya titik kompensasi cahaya sehingga dapat mengakumulasi produk fotosintat pada tingkat cahaya yang rendah dibandingkan dengan tanaman cahaya penuh.

Cruz (1997) menyatakan naungan dapat mengurangi enzim fotosintetik yang berfungsi sebagai katalisator dalam fiksasi $\mathrm{CO}_{2}$ dan menurunkan titik kompensasi cahaya. Pengaruh intensitas cahaya yang rendah terhadap hasil berbagai komoditi sudah banyak dilaporkan. Naungan $50 \%$ pada genotipe padi yang sensitif menyebabkan jumlah gabah/malai kecil serta persentase gabah hampa yang tinggi, sehingga produksi biji rendah (Sopandie et al. 2003). Intensitas cahaya rendah pada saat pembungaan padi dapat menurunkan karbohidrat yang terbentuk, sehingga menyebabkan meningkatnya gabah hampa (Chaturvedi et al. 1994). Intensitas cahaya rendah menurunkan hasil kedelai (Asadi et al. 1997), jagung (Andre et al. 1993), padi gogo (Supriyono et al. 2000), ubi jalar (Nurhayati et al. 1985), dan talas (Caiger 1986, Wirawati et al. 2002).

Pengurangan cahaya pada tanaman yang telah memperoleh cahaya, suhu dan kelembaban yang optimum akan menyebabkan pengurangan pertumbuhan akar dan tanaman menunjukkan gejala etiolasi (Williams dan Joseph 1976). Intensitas, kualitas dan lamanya penyinaran mempengaruhi proses fotosintesis, tetapi yang terpenting adalah intensitasnya (Daniel et al. 1979). Selanjutnya intensitas cahaya berpengaruh terhadap pembesaran dan diferensiasi sel (Soekotjo 1977). Ruas batang tanaman lebih panjang dan tersusun dari sel-sel berdinding tipis dengan ruang antar sel lebih besar, jaringan pengangkut dan penguat lebih sedikit. Intensitas cahaya yang rendah juga membuat tanaman memiliki daun berukuran lebih besar, lebih tipis, ukuran stomata lebih besar, lapisan sel 
epidermis tipis, jumlah daun lebih banyak dan ruang antar sel lebih banyak (Treshow 1970).

Agar mampu beradaptasi pada lingkungan dengan intensitas cahaya rendah, tanaman mengalami berbagai perubahan pada tingkat molekuler, biokimia, anatomi, morfologi, fisiologi, dan agronomi (Sopandie et al. 2001, Khumaida 2002, Juraimi et al. 2004).

Kedelai merupakan salah satu sumber protein nabati dengan kandungan $39 \%$. Pada umumnya petani mengusahakan palawija termasuk kedelai setelah padi di sawah yaitu pada saat irigasi dihentikan atau saat menjelang kemarau tiba (Agung dan Rahayu 2004). Pengembangan tanaman kedelai sebagai tanaman sela di bawah tegakan karet, hutan tanaman industri ( $\mathrm{HTI})$, atau tumpangsari dengan tanaman pangan semusim lain merupakan alternatif andalan untuk meningkatkan produksi kedelai. Hanya saja kendala utama pengembangan kedelai sebagai tanaman sela atau tumpangsari tersebut adalah rendahnya intensitas cahaya akibat faktor naungan. Ratarata intensitas cahaya berkurang 25$50 \%$ di bawah tegakan karet berumur 2-3 tahun (Chozin et al. 1999), sedangkan pada tumpangsari dengan jagung berkurang 33\% (Asadi et al. 1997) dari rata-rata intensitas cahaya di lingkungan terbuka $800 \mathrm{kal} / \mathrm{cm}^{2} /$ hari. Cekaman naungan $50 \%$ menyebabkan hasil per hektar tanaman kedelai menurun 10-40\%. Penelitian ini bertujuan untuk mengamati respons morfologi dan anatomi kecambah kacang kedelai pada stadium vegetatif 3 terhadap perbedaan intensitas cahaya.

\section{METODE}

Bahan-bahan yang digunakan yaitu kacang kedelai (Glycine max (L.) Merill), air, paranet 65\%; polybag $20 \times 3 \mathrm{~cm}$ sebanyak 27 buah; dan media tanam kompos mix. Alatalat yang digunakan pada penelitian ini meliputi: bambu, paku, tali, lem, kertas A4, pagar bambu, termometer infra merah, mikroskop cahaya, light meter, skymate, mistar, silet, kaca benda, kaca penutup, pipet tetes, laptop, optilab, alat tulis menulis, dan scanner. Penelitian ini dilakukan pada bulan Juni 2011 sampai dengan Juli 2011 di Kelurahan Bahu (halaman rumah peneliti). Kemudian dilanjutkan dengan pengamatan di Laboratorium Konservasi Jurusan Biologi, Fakultas Matematika dan IImu Pengetahuan Alam Universitas Sam Ratulangi.

Penelitian ini dilakukan dengan menggunakan Rancangan Acak Lengkap (RAL) dengan satu faktor tunggal yaitu intensitas cahaya, dengan tiga taraf perlakuan yaitu PO (tanpa naungan), P1 (naungan paranet 1 lapis atau setara dengan naungan $\pm 50 \%$ ) dan P2 (naungan paranet 2 lapis atau setara dengan naungan $\pm 90 \%$ ). Setiap perlakuan diulang tiga kali. Penelitian ini menggunakan satu varietas kacang kedelai. Kacang kedelai yang digunakan dipilih, kemudian dikecambahkan di polybag. Polybag diisi dengan media tanam kompos mix sebanyak $3 / 4$ dari ukuran polybag. Pada masing-masing perlakuan yaitu paranet $50 \%, 90 \%$, dan tanpa naungan diletakkan polybag yang berisi benih kacang kedelai.

Setelah 14 hari perlakuan akan dilakukan pengamatan terhadap iklim mikro tanaman. Pengamatan ini dimaksudkan untuk melihat rata-rata iklim mikro tanaman selama penelitian yang datanya kemudian digunakan untuk melihat pengaruhnya terhadap metabolisme tanaman. Iklim mikro diamati pada hari ke-14 sampai hari ke-18 dengan tiga kali pengukuran yaitu pada jam 07.00 pagi, 12.00 siang, dan 05.00 sore. Iklim mikro yang diamati yaitu 
Intensitas cahaya diukur dengan menggunakan light meter; temperatur lingkungan diukur dengan menggunakan termometer; Temperatur daun diukur menggunakan termometer nonkontak atau termometer infra merah; Kelembaban udara diukur dengan hygrometer; Kecepatan angin diukur dengan menggunakan skymate.

Pertumbuhan tanaman diamati pada hari ke-26. Untuk mengamati pertumbuhan tanaman digunakan 2 sampel tanaman kacang kedelai di tiap polybag pada semua perlakuan. Pengamatan morfologi tanaman ini menggunakan tanaman atau sampel yang sama untuk semua parameter yang diamati. Oleh karena itu, pengamatan ini dilakukan pada hari yang sama. Parameter yang diamati meliputi respons morfologi (tinggi tanaman, luas daun, dan jumlah daun) dan respons anatomi yaitu jumlah, panjang dan diameter stomata per satuan bidang pandang mikroskop. Pengamatan ini menggunakan sampel yang sama dengan yang digunakan pada pengamatan morfologi tanaman. Data yang diperoleh dianalisis dengan ANOVA. Jika terdapat perbedaan nyata, akan dilanjutkan dengan uji BNT $5 \%$.

\section{HASIL DAN PEMBAHASAN}

Perbedaan tingkat naungan mempengaruhi intensitas cahaya, suhu udara, dan kelembaban udara lingkungan tanaman, sehingga intensitas cahaya yang diterima oleh tanaman berbeda dan mempengaruhi ketersediaan energi cahaya yang akan diubah menjadi energi panas dan energi kimia. Apabila energi cahaya tidak dilepaskan kembali ke lingkungannya, energi tersebut akan diubah menjadi energi panas dan akan menaikkan suhu daun sedangkan energi cahaya diubah menjadi energi kimia yaitu melalui proses fotosintesis dengan menghasilkan karbohidrat yang digunakan tanaman dalam proses pertumbuhannya. Perlakuan naungan $50 \%$ dan tanpa naungan menyebabkan intensitas cahaya yang diterima tanaman berkisar antara 12.886,67 lux sampai 36.840 lux. Tanaman kedelai tumbuh dengan baik dengan intensitas cahaya tersebut, sehingga diperkirakan tanaman kedelai tumbuh pada intensitas cahaya optimum berkisar pada 36.840 lux. Intensitas cahaya yang diterima tanaman pada naungan $50 \%$ hanya sebesar 35\% dan naungan $90 \%$ menerima cahaya $27 \%$, jika dibandingkan dengan intensitas cahaya pada areal tanpa naungan (Tabel 1).

Tabel 1. Rata-rata pengamatan pengaruh naungan terhadap iklim mikro pada tanaman kacang kedelai.

\begin{tabular}{|c|c|c|c|}
\hline $\begin{array}{l}\text { Tingkat } \\
\text { Naungan }\end{array}$ & P0 & P1 & P2 \\
\hline $\begin{array}{l}\text { Suhu daun } \\
\left({ }^{\circ} \mathrm{C}\right)\end{array}$ & 28,2 & 27,43 & 27,85 \\
\hline $\begin{array}{l}\text { Intensitas } \\
\text { Cahaya (Lux) }\end{array}$ & 36.840 & $12.886,67$ & $10.026,67$ \\
\hline $\begin{array}{l}\text { Kelembaban } \\
(\%)\end{array}$ & 77,92 & 75,33 & 76,04 \\
\hline $\begin{array}{l}\text { Suhu Dalam } \\
\left({ }^{\circ} \mathrm{C}\right)\end{array}$ & 30,86 & 30,46 & 30,31 \\
\hline $\begin{array}{l}\text { Suhu Luar } \\
\left({ }^{\circ} \mathrm{C}\right)\end{array}$ & & 30,33 & \\
\hline $\begin{array}{l}\text { Kecepatan } \\
\text { Angin }(\mathrm{m} / \mathrm{s})\end{array}$ & & 0,76 & \\
\hline \multicolumn{4}{|c|}{$\begin{array}{l}\text { Keterangan: Iklim mikro tanaman diukur } \\
\text { selama } 5 \text { hari, dengan tiga kali pengukuran } \\
\text { setiap harinya yaitu pagi, siang dan sore } \\
\text { hari. P0: tanpa naungan, P1: naungan } 50 \% \\
\text { dan P2: naungan } 90 \%\end{array}$} \\
\hline
\end{tabular}

Kelembaban udara yang terlalu rendah dan terlalu tinggi akan menghambat pertumbuhan dan pembungaan tanaman. Kelembaban udara dapat mempengaruhi pertumbuhan tanaman karena dapat mempengaruhi proses fotosintesis. Laju fotosintesis meningkat dengan meningkatnya kelembaban udara sekitar tanaman (Kramer dan Kozlowski 1979).

Iklim mikro mempengaruhi transpirasi antara lain radiasi cahaya mempengaruhi membukanya 
stomata, sehingga transpirasi berjalan lancar. Kenaikan suhu udara akan mempengaruhi kelembaban. Kelembaban menunjukkan banyak sedikitnya uap air di udara, makin banyaknya uap air di udara, akan makin kecil perbedaan tekanan uap air dalam rongga daun dengan di udara maka makin lambat laju transpirasi. Angin adalah suatu perpindahan massa udara dari satu tempat ke tempat lain. Dalam perpindahan massa udara ini, angin akan membawa masa uap air yang berada di sekitar tumbuhan, sehingga dapat menurunkan tekanan uap air di sekitar daun dan dapat mengakibatkan menurunnya transpirasi. Apabila angin bertiup terlalu kencang, dapat mengakibatkan uap air keluar melebihi kemampuan daun untuk menggantinya dengan air yang berasal dari tanah, sehingga daun akan mengalami kekurangan air, turgor sel akan menurun termasuk turgor sel penutup dan akhirnya stomata dapat menutup (Sasmitamihardja et al. 1996).

Respons morfologi tanaman kacang kedelai yang diukur pada penelitian ini meliputi tinggi tanaman, jumlah daun dan luas daun (Tabel 2).

Tabel 2. Rata-rata dan standar deviasi (SD) respons morfologi tanaman kacang kedelai pada tiga perlakuan cahaya yang berbeda.

\begin{tabular}{ccccc} 
& Des- & $\mathrm{P} 0$ & $\mathrm{P} 1$ & $\mathrm{P} 2$ \\
\cline { 3 - 5 } No & kripsi & $\mathrm{N}=18$ & $\mathrm{~N}=18$ & $\mathrm{~N}=18$ \\
\cline { 3 - 5 } & Morfo- & Rata- & Rata- & Rata- \\
& logi & rata \pm SD & rata \pm SD & rata $\pm S D$ \\
\hline \multirow{3}{*}{1.} & Tinggi & $34,85 \pm$ & $48,22 \pm$ & $73,36 \pm 1$ \\
& Tanam- & 9,63 & 17,06 & 7,57 \\
& an (cm) & $\mathrm{a}$ & $\mathrm{b}$ & $\mathrm{C}$ \\
& Jumlah & $13 \pm$ & $15 \pm$ & $17 \pm$ \\
2. & Daun & 2,28 & 4,86 & 5,19 \\
& & $\mathrm{a}$ & $\mathrm{ab}$ & $\mathrm{b}$ \\
& Luas & $13,18 \pm$ & $11,82 \pm$ & $9,83 \pm$ \\
3. & Daun & 2,44 & 2,41 & 1,99 \\
& $\left(\mathrm{~cm}^{2}\right)$ & $\mathrm{a}$ & $\mathrm{b}$ & $\mathrm{b}$ \\
\hline
\end{tabular}

Keterangan : Angka-angka yang diikuti huruf yang sama dalam baris yang sama menunjukkan hasil tidak berbeda nyata pada uji BNT 5\%. P0: tanpa naungan, P1: naungan $50 \%$ dan $\mathrm{P} 2$ : naungan $90 \%$
Hasil uji Anova menunjukkan bahwa tinggi tanaman berbeda nyata pada tiga perlakuan intensitas cahaya yang berbeda. Dengan uji BNT (5\%) diperoleh bahwa tinggi tanaman paling besar terdapat pada perlakuan P2 yaitu $73,36 \mathrm{~cm}$. Tinggi tanaman P1 adalah 52,13\% lebih kecil daripada tinggi tanaman P2 sedangkan tinggi tanaman P0 $38,36 \%$ lebih kecil daripada tinggi tanaman P1 (Tabel 2). Hasil penelitian ini menunjukkan bahwa tinggi tanaman P2 47,87\% lebih besar dibandingkan dengan tinggi tanaman P1. Perbedaan tinggi tanaman disebabkan oleh besarnya intensitas cahaya yang diterima oleh tanaman dan berkaitan dengan hormon tanaman yaitu auksin. Tanaman yang tumbuh di bawah naungan memperoleh intensitas cahaya yang rendah sehingga tidak mengalami kerusakan auksin. Selain itu, pertumbuhan tinggi tanaman yang terbesar pada P2 merupakan gejala etiolasi yaitu batang kecambah akan tumbuh lebih cepat tetapi lemah dan berwarna kuning akibat kekurangan cahaya (Zhamal 2008).

Hasil analisis tanaman kacang kedelai menunjukkan bahwa perlakuan naungan 90\% dengan intensitas cahaya rendah mengakibatkan peningkatan jumlah daun. Uji BNT 5\% menunjukkan jumlah daun tidak berbeda antara perlakuan P0 dengan P1 dan antara P1 dan P2. Tetapi jumlah daun berbeda nyata antara P0 dan P2 yaitu jumlah daun pada P2 32,74\% lebih besar dibandingkan dengan jumlah daun P0 (Tabel 2).

Jumlah daun menjadi penentu utama kecepatan pertumbuhan (Fitter dan Hay 1992) dalam Marjenah 2001). Keadaan ini terlihat pada hasil penelitian, yaitu daundaun dengan luas daun yang lebih besar mempunyai pertumbuhan yang besar pula. Morfologi daun yang lebar dan tipis diperlukan pada 


\section{JURNAL BIOSLOGOS, AGUSTUS 2012, VOL. 2 NOMOR 2}

kondisi lingkungan cahaya kurang untuk dapat menangkap cahaya sebanyak mungkin dengan cahaya yang direfleksikan serendah mungkin. Peningkatan luas daun memungkinkan peningkatan luas bidang tangkapan dan juga menyebabkan daun menjadi lebih tipis karena sel-sel palisade hanya terdiri dari satu atau dua lapis (Khumaida 2002).

Daun di tempat ternaung biasanya lebih lebar dan tipis dan memungkinkan penangkapan cahaya lebih banyak untuk diteruskan ke bagian bawah daun dengan cepat, sehingga kegiatan fotosintesis berlangsung maksimal. Penipisan daun disebabkan oleh berkurangnya lapisan palisade pada sel mesofil daun (Taiz dan Zeiger 1991). Selanjutnya, pada genotipe padi gogo dan kedelai toleran naungan terjadi pengurangan lapisan palisade yang lebih besar akibat cekaman naungan, sehingga menyebabkan daun menjadi lebih tipis. Perubahan karakter tersebut diduga merupakan bentuk mekanisme penghindaran terhadap cahaya rendah (Khumaida 2002, Sopandie et al. 2003). Respons menghindar (shade avoidance response) pada tanaman yang mengalami cekaman intensitas cahaya rendah dilakukan dengan memaksimalkan penangkapan cahaya dengan cara mengubah anatomi dan morfologi daun untuk fotosintesis yang efisien (Evans dan Poorter 2001).

Uji Anova menunjukkan terdapat perbedaan luas daun yang nyata antara P0 dengan P1 dan P2 sedangkan $\mathrm{P} 1$ dan $\mathrm{P} 2$ tidak berbeda. Pada uji BNT 5\% menunjukkan bahwa luas daun P0 $11,5 \%$ lebih besar dibandingkan dengan luas daun P1 dan 34,07\% lebih besar daripada luas daun P2 (Tabel 2). Luas daun di tempat ternaung lebih kecil dari luas daun pada tempat terbuka. Luas daun pada tempat terbuka adalah luas yang normal dengan warna yang hijau tua dan tebal. Daun ditempat ternaung lebih kecil dan tipis, diduga kemungkinan tanaman beradaptasi dengan meningkatkan jumlah daun bukan dengan luas daun. Selain itu, proses fotosintesis pula dipengaruhi oleh jumlah cahaya yang di terima oleh daun. Tanaman kedelai memiliki daun yang berbulu. Bulu daun merupakan organ yang mampu memantulkan cahaya. Dengan demikian, semakin sedikit jumlah bulu daun yang ada dipermukaan daun maka peluang untuk memantulkan cahaya menjadi kecil, sehingga cahaya dapat langsung diterima oleh daun. Hal ini diperkuat oleh hasil penelitian Bjorkman dan Adam (1994) dalam Xu dan Shen (1999) yang menyatakan bahwa bulu daun berperan sebagai reflektan, sehingga daun dengan banyak bulu di permukaan atas daun, mempunyai kemampuan memantulkan cahaya lebih besar. Menurut Levitt (1980) pengurangan jumlah bulu daun merupakan salah satu mekanisme yang dikembangkan tanaman untuk menghindari cekaman kekurangan cahaya.

Respons anatomi tanaman kacang kedelai yang diukur pada penelitian ini meliputi jumlah stomata, panjang stomata dan diameter stomata (Tabel 3).

Tabel 3. Rata-rata dan standar deviasi (SD) respons anatomi tanaman kacang kedelai pada tiga perlakuan cahaya yang berbeda

\begin{tabular}{|c|c|c|c|c|}
\hline \multirow{3}{*}{ No } & \multirow{3}{*}{$\begin{array}{l}\text { Deskripsi } \\
\text { Anatomi }\end{array}$} & P0 & P1 & $\mathrm{P} 2$ \\
\hline & & $\mathrm{N}=3$ & $\mathrm{~N}=3$ & $\mathrm{~N}=3$ \\
\hline & & $\begin{array}{l}\text { Rata- } \\
\text { rata } \pm S D\end{array}$ & $\begin{array}{l}\text { Rata- } \\
\text { rata } \pm S D\end{array}$ & $\begin{array}{l}\text { Rata- } \\
\text { rata } \pm S D\end{array}$ \\
\hline 1. & $\begin{array}{l}\text { Jumlah } \\
\text { Stomata } \\
\text { Panjang }\end{array}$ & $9 \pm 2,64$ & $12 \pm 4,58$ & $11 \pm 4,06$ \\
\hline 2. & $\begin{array}{l}\text { Stomata } \\
(\mu \mathrm{m}) \\
\text { Diameter }\end{array}$ & $7,3 \pm 1,85$ & $7,1 \pm 0,6$ & $7,5 \pm 0,3$ \\
\hline 3. & $\begin{array}{l}\text { Stomata } \\
(\mu \mathrm{m})\end{array}$ & $3,5 \pm 1,05$ & $3,2 \pm 0,6$ & $3,6 \pm 0,5$ \\
\hline
\end{tabular}

Keterangan : P0: tanpa naungan, P1: naungan $50 \%$ dan P2: naungan $90 \%$ 
Hasil penelitian menunjukkan bahwa $F$ hitung lebih kecil dari $F$ tabel, sehingga pengujian tidak dilanjutkan dengan uji BNT 5\%. Perlakuan naungan tidak memberikan respons atau pengaruh nyata (tidak signifikan) terhadap jumlah stomata, panjang stomata dan diameter stomata.

Sutarmi (1983) menyatakan bahwa tanaman kacang kedelai dapat beradaptasi dengan meningkatkan jumlah, panjang dan diameter stomata untuk meningkatkan hasil fotosintesis. Dengan intensitas cahaya yang rendah, tanaman menghasilkan daun lebih besar, lebih tipis dengan lapisan epidermis tipis, jaringan palisade sedikit, ruang antar sel lebih lebar dan jumlah stomata lebih banyak. Sebaliknya pada tanaman yang menerima intensitas cahaya tinggi menghasilkan daun yang lebih kecil, lebih tebal, lebih kompak dengan jumlah stomata lebih sedikit, lapisan kutikula dan dinding sel lebih tebal dengan ruang antar sel lebih kecil dan tekstur daun keras. Hasil penelitian Morais et al. (2004), menunjukkan bahwa jumlah stomata daun pada perlakuan tanpa naungan lebih banyak dibandingkan dengan perlakuan naungan. Hasil ini juga sejalan dengan pernyataan Bolhar Nordenkampf et al. (1993), bahwa tanaman di bawah naungan memiliki sedikit stomata. Pada beberapa tanaman seperti kimpul (Xanthosoma sagittifolium), ubijalar (Ipomoea batatas), gembili (Dioscorea esculenta), dan ubikayu (Manihot esculenta), naungan mengakibatkan pengurangan kepadatan stomata. Hasil penelitian menunjukkan tidak terdapat perbedaan yang nyata. Hal ini mungkin disebabkan oleh kurangnya waktu yang digunakan dalam perlakuan penelitian ini (stadium vegetatif 3) dan faktor genetik yang dimiliki oleh varietas yang digunakan.

\section{KESIMPULAN}

Morfologi tanaman kedelai pada stadium vegetatif 3 dipengaruhi oleh intensitas cahaya. Tinggi tanaman pada perlakuan naungan $90 \%$ dua kali lebih besar dibandingkan dengan tinggi tanaman tanpa naungan; jumlah daun tidak berbeda antara perlakuan tanpa naungan dengan naungan $50 \%$ dan antara perlakuan naungan $50 \%$ dan $90 \%$, tetapi jumlah daun pada naungan $90 \%$ lebih banyak dibandingkan dengan jumlah daun tanpa naungan dan luas daun pada perlakuan tanpa naungan lebih besar dibandingkan dengan luas daun pada perlakuan naungan 50 dan 90\%. Anatomi tanaman kedelai (jumlah, panjang, dan diameter stomata) pada stadium vegetatif 3 tidak dipengaruhi oleh intensitas cahaya.

\section{UCAPAN TERIMA KASIH}

Penulis menyampaikan terima kasih kepada Ir. Feky Mantiri, M.Sc., Ph.D., Dra. Nio Song Ai, M.Si., Ph.D dan Dr. Dingse Pandiangan, M.Si selaku dosen pembimbing yang telah membantu penulis menyelesaikan tugas akhir ini.

\section{DAFTAR PUSTAKA}

Agung T, Rahayu AY (2004) Analisis efisiensi serapan N, pertumbuhan, dan hasil beberapa kultivar kedelai unggul baru dengan cekaman kekeringan dan pemberian pupuk hayati. Agrosains 6: 70-74.

Andre $\mathrm{FH}$, Uhart $\mathrm{SH}$, Frugone $\mathrm{MI}$ (1993) Intercepted radiation at flowering and kernel number in maize: shade versus plant density effects. Crop Sci 33: 482-485

Asadi D, Arsyad M, Zahara $\mathrm{H}$, Darmijati (1997) Pemuliaan kedelai untuk toleran naungan dan tumpangsari. Buletin Agrobio. Vol. 1 (2):15-20

Bolhar-Nordenkampf HR, Draxler G (1993) Functional leaf anatomy. Dalam: Hall DO, Scurlock JMO, 
Bolhar - Nordenkampf HR, Leegood RC, Long SP (eds) Photosynthesis and production in a changing environment. A Field and Laboratory Manual, Chapman \& Hall, London. pp 91112

Caiger S (1986) Effect of shade on yield of taro cultivars in Tuvalu. Agric. Bulletin 11:66-68

Chaturvedi GSP, Ram C, Singh AK, Ram $\mathrm{P}$, Ingram KT, Singh BB, Singh RK, Singh VK (1994) Carbohydrate status of rainfed lowland ricein relation to submergence, drought and shade tolerance. Dalam: Proceeding Physiology of Stress Tolerance in Rice, Los Banos: IRRI Philippines, pp 104-122

Chozin MA, Sopandie D, Sastrosumajo S, Sumarno (1999) Physiology and genetic of upland rice adaptation to shade. Final Report of Graduate Team Research Grant, URGE Project. Directorate General of Higher Education, Ministry of Education and Culture

Cruz P (1997) Effect of shade on the growth and mineral nutrition of $\mathrm{C} 4$ perennial grass under field conditions. Plant and Soil 188:227-237

Daniel TW, Helm JW, Baker FS (1979) Principles of silviculture, Edisi ke-2. Mc.Graw Hill, Inc., New York

Da-Quan X, Yun-Kang S (1999) Light stress: photoinhibition of photosynthesis in plant under natural conditions. Dalam: Passarakli M (ed) Handbook of plant and crop stress. Edisi ke-2. Marcel Dekker, Inc, New York, pp 483-497

Evans JR, Poorter H (2001) Photosynthetic acclimation of plants to growth irradiance: the relative importance of specific leaf area and nitrogen partitioning in maximizing carbon gain. Plant Cell Environ 24:755-767.
Gardner FP, Pearce RB, Mitchell RL (1991) Physiology of crop plants. Diterjemahkan oleh $\mathrm{H}$. Susilo. Universitas Indonesia Press, Jakarta.

Hale MG, Orcutt DM (1987) The Physiology of plants under stress. John Wiley and Sons, New York.

Juraimi AS, Drennan DSH, Anuar N (2004) The effects of shading on the growth, development and partitioning of biomass in bermudagrass (Cynodondactylon (L.) Pers). J Biol Sci 4:756-762

Khumaida N (2002) Studies on adaptability of soybean and upland rice to shade stress. Disertasi. The University of Tokyo, Tokyo

Kramer PJ, Kozlowski TT (1979) Physiology of woody plant. Academic Press, New York

Levitt J (1980) Responses of plants to environmental stresses.water, radiation, salt, and other stresses. Vol. II. Academic Press, Inc, London

Marjenah (2001) Pengaruh perbedaan naungan di persemaian terhadap pertumbuhan dan respon morfologi dua jenis semai meranti. Jurnal IImiah Kehutanan "Rimba Kalimantan" 6

Morais $\mathrm{H}$, Medri ME, Marur CJ, Caramori $\mathrm{PH}$, de Arrura Ribeiro AM, Gomes JC (2004) Modifications on leaf anatomy of Coffea arabica caused by shade of pigeonpea (Cajanus cajan). Brazilian Archives of Biology and Technology. 47: 863-871

Nurhayati AP, Lontoh, Koswara J (1985) Pengaruh intensitas dan saat pemberian naungan terhadap produksi ubi jalar (Ipomoea batatas (L.) Lamp.). Bul. Agr 16:28-38

Sasmitamihardja D, Siregar A (1996)

Fisiologi Tumbuhan. ITB, Bandung 
Soekotjo W (1977) Silvikultur khusus. Akademi Ilmu Kehutanan (AlK), Bandung

Sopandie D, Chozin MA, Sastrosumarjo S, Juhaeti $\mathrm{T}$, Sahardi (2003) Toleransi padi gogo terhadap naungan. Hayati 10: 71-75

Sopandie D, Chozin MA, Khumaida N, Takano T (2001) Differential shading tolerance of upland rice genotypes related to rubisco activity and its gen expression. Dalam: Proceeding of The 1st Seminar Toward Harmonization between Development and Environmental Conservation in Biological Production. Tokyo University, Tokyo

Supriyono B, Chozin MA, Sopandie D, Darusman LK (2000) Perimbangan pati-sukrosa dan aktivitas enzim sukrosa fosfat sintase pada padi gogo yang toleran dan peka terhadap naungan. Hayati 7:31-34
Sutarmi S (1983) Botani Umum Jilid II. Angkasa, Bandung

Taiz L, Zeiger E (1991) Plant Physiology. The Benyamin/Cumming Publishing Company Inc, Tokyo, pp 219-247

Treshow ML (1970) Environment and plant response. Mc Graw Hill Company, New York

Williams CN, Joseph KT (1976) Climate, soil and crop production in the humid tropes. Oxford University Press, Kuala Lumpur, pp 177

Wirawati T, Purwoko BS, Sopandie D, Hanarida I (2002) Studi fisiologi adaptasi talas terhadap kondisi naungan. Seminar Program Pasca Sarjana. Program Pascasarjana IPB, Bogor.

Zhamal (2008) Pengaruh cahaya terhadap pertumbuhan biji kacang hijau.

http:// catatanzhamal.blogspot.com/.

Diakses pada April 2010 